\title{
\#USES
}

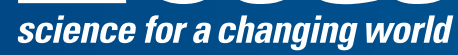

Prepared in cooperation with the

Alaska Department of Transportation and Public Facilities and

Federal Highway Administration

\section{Calculation of Scour Depth at the Parks Highway Bridge on the Tanana River at Nenana, Alaska, Using One- and Two-Dimensional Hydraulic Models}

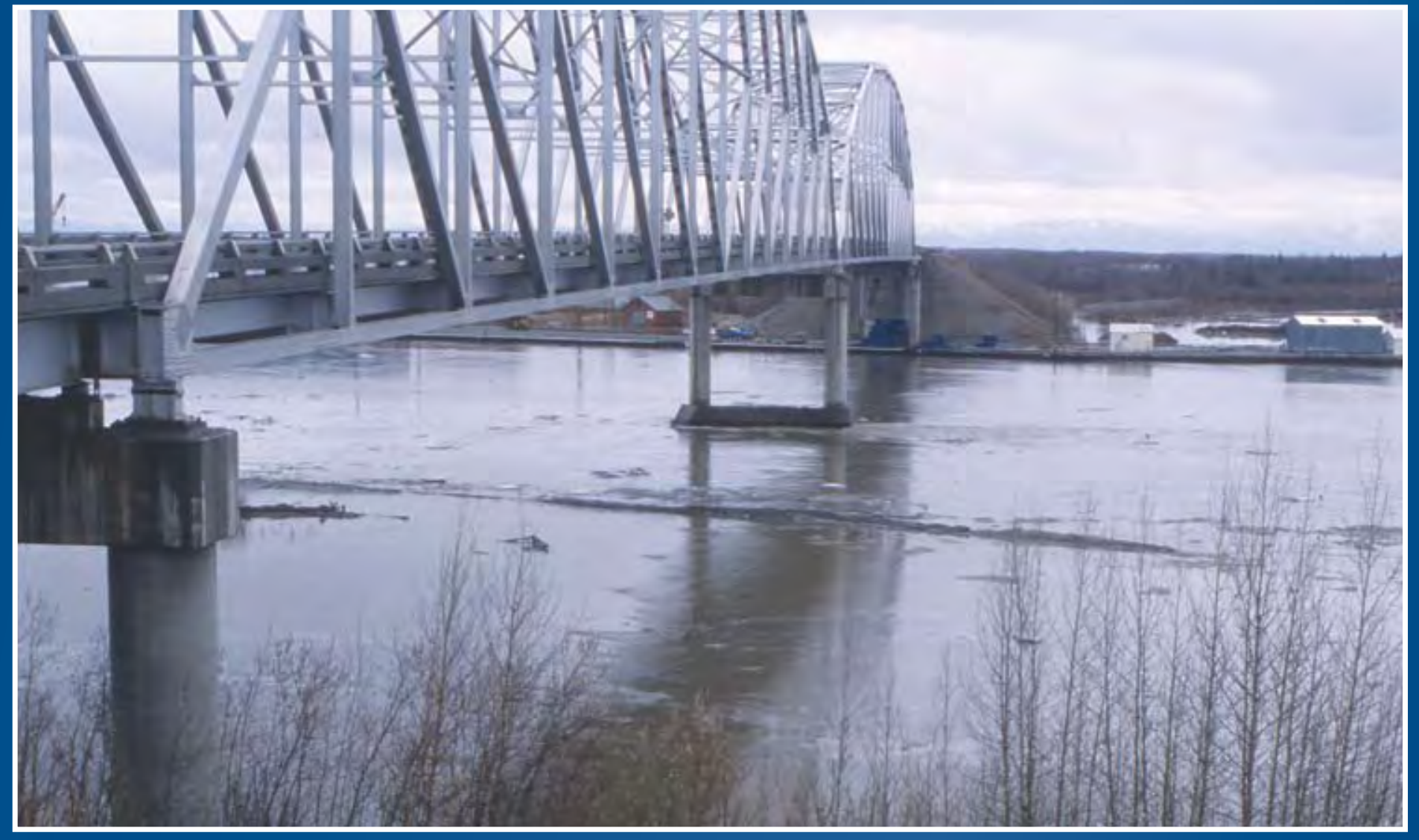

Scientific Investigations Report 2006-5023 
Cover: Photograph of the Tanana River at Nenana, Alaska, looking south from the northern highway bridge abutment. (Photograph taken by Robert Burrows, U.S. Geological Survey, May 4, 1989). 


\section{Calculation of Scour Depth at the Parks Highway Bridge on the Tanana River at Nenana, Alaska, Using One- and Two-Dimensional Hydraulic Models}

By Dustin E. Langley

Prepared in cooperation with the Alaska Department of Transportation and Public Facilities and Federal Highway Administration

Scientific Investigations Report 2006-5023 


\title{
U.S. Department of the Interior \\ Gale A. Norton, Secretary \\ U.S. Geological Survey \\ P. Patrick Leahy, Acting Director
}

\section{U.S. Geological Survey, Reston, Virginia: 2006}

\author{
For sale by U.S. Geological Survey, Information Services \\ Box 25286, Denver Federal Center \\ Denver, CO 80225 \\ For more information about the USGS and its products: \\ Telephone: 1-888-ASK-USGS \\ World Wide Web: http://www.usgs.gov/
}

\footnotetext{
Any use of trade, product, or firm names in this publication is for descriptive purposes only and does not imply endorsement by the U.S. Government.

Although this report is in the public domain, permission must be secured from the individual copyright owners to reproduce any copyrighted materials contained within this report.

Suggested citation:

Langley, D.E., 2006, Calculation of scour depth at the Parks Highway Bridge on the Tanana River at Nenana, Alaska, using one- and two-dimensional hydraulic models: U.S. Geological Survey Scientific Investigations Report 2006-5023, $19 p$.
} 


\section{Contents}

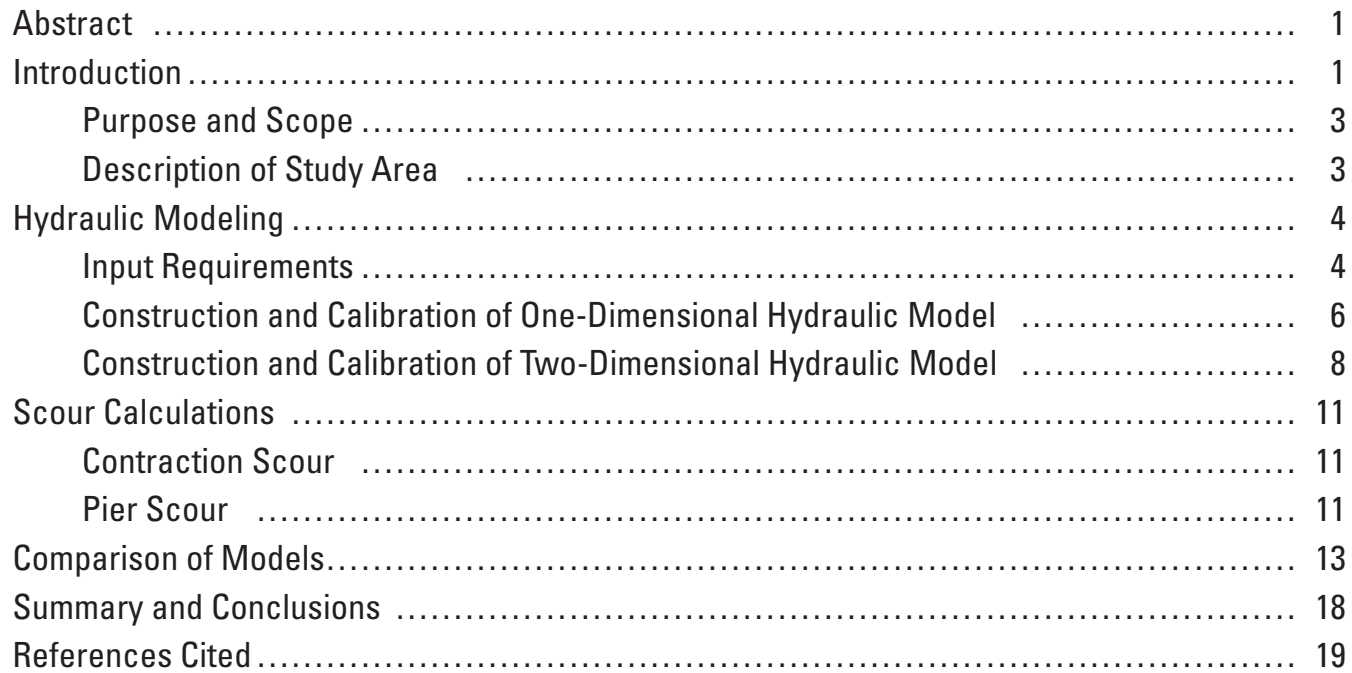

\section{Figures}

Figure 1. Map showing location of the Parks Highway Bridge (Alaska Department of Transportation and Public Facilities Bridge \#201) scour-analysis site on the Tanana River at Nenana, Alaska, and the reach included in hydraulic models ...... 2

Figure 2. Hydrograph showing maximum, mean, and minimum daily discharge for 38 years of record (1962-2000) for U.S. Geological Survey streamflow-gaging station 15515500, Tanana River at Nenana, Alaska

Figure 3. Graph showing grain-size distribution of bed-sediment samples collected by the U.S. Geological Survey from Tanana River at Nenana, Alaska, June 7,1964

Figure 4. Plan view showing cross sections and river stations, hydraulic model center lines, and river junctions used in the one-dimensional model for scour analysis of Tanana River at Nenana, Alaska

Figure 5. Plan view showing model mesh and streambed elevations used for the two-dimensional model of Tanana River at Nenana, Alaska

Figure 6. Graphs showing water-surface profiles for six discharge scenarios on Tanana River at Nenana, Alaska, simulated using one- and two-dimensional hydraulic models

Figure 7. Plan views showing velocity vectors and magnitudes on the Tanana River near the mouth of the Nenana River, Alaska, simulated using a two-dimensional hydraulic model

Figure 8. Graph showing comparison of discharge in Tanana Slough for six discharge scenarios simulated using one- and two-dimensional hydraulic models 


\section{Figures-Continued}

Figure 9. Graph showing depth of pier scour, calculated using output from one- and two-dimensional hydraulic models, and angle of attack at bridge pier 3 for five discharge scenarios representing floods on the Tanana River near Nenana, Alaska

Figure 10. Graph showing streamflow velocity along cross-section 1.377 on the Tanana River near Nenana, Alaska, measured on August 19, 1998, and simulated using one- and two-dimensional hydraulic models

\section{Tables}

Table 1. Estimated annual sediment load of the Tanana River, Alaska, 1977-79....

Table 2. Boundary conditions for discharge scenarios for the Tanana River at Nenana, Alaska, simulated using one- and two-dimensional hydraulic models

Table 3. Material types and associated roughness values for the Tanana River at Nenana, Alaska

Table 4. Values used to calibrate the two-dimensional hydraulic model for the Tanana River at Nenana, Alaska

Table 5. Calculated depths of pier scour, contraction scour, and angles of attack at pier 3, and associated variables, Tanana River at Nenana, Alaska

\section{Conversion Factors and Datums}

Conversion Factors

\begin{tabular}{lll}
\hline \multicolumn{1}{c}{ Multiply } & \multicolumn{1}{c}{ By } & \multicolumn{1}{c}{ To obtain } \\
\hline cubic foot per second $\left(\mathrm{ft}^{3} / \mathrm{s}\right)$ & 0.02832 & cubic meter per second \\
foot $(\mathrm{ft})$ & 0.3048 & meter \\
feet per foot $(\mathrm{ft} / \mathrm{ft})$ & 1 & meter per meter \\
foot per second $(\mathrm{ft} / \mathrm{s})$ & 0.3048 & meter per second \\
foot per square second $\left(\mathrm{ft} / \mathrm{s}^{2}\right)$ & 0.3048 & meter per square second \\
mile (mi) & 1.609 & kilometer \\
million gallons per year $(\mathrm{Mgal} / \mathrm{yr})$ & 0.04381 & cubic meter per year \\
pound per second per square foot $\left.(\mathrm{lb} / \mathrm{s}) / \mathrm{ft}^{2}\right)$ & 4.882 & kilograms per second per square meter \\
\hline
\end{tabular}

Grain size in streambed sediments is given in millimeters $(\mathrm{mm})$.

Slope is given in feet per foot (ft/ft).

Datums

Vertical coordinate information is referenced to the National Geodetic Vertical Datum of 1929 (NGVD 29).

Horizontal coordinate information was arbitrarily set at time of survey. 


\section{Calculation of Scour Depth at the Parks Highway Bridge on the Tanana River at Nenana, Alaska, Using One-and Two-Dimensional Hydraulic Models}

\author{
By Dustin E. Langley
}

\section{Abstract}

The Parks Highway crossing of the Tanana River at Nenana, Alaska, is a hydraulically complex site. Both the confluence of the Nenana River and the division of the Tanana River by an island into a main channel and a side channel, or slough, affect flow. A recent study determined that the large pier on the bridge over the main channel was susceptible to damage by scour. Further investigations were required to estimate the risk of pier scour and contraction scour at high flows.

The reach of the Tanana River that includes the confluence of the Nenana River and the Tanana Slough was surveyed on August 17-20, 1998. Channel geometry from this survey was used as input for two hydraulic models: a one-dimensional model and a two-dimensional model. Each model was calibrated to a high discharge measurement taken on August 17, 1967. Discharge scenarios were simulated for the discharge of August 17, 1967, and for floods in the Tanana River with 100- and 500-year recurrence intervals, each run with a low and a high discharge in the Nenana River. Low discharge simulated for the Nenana River was the discharge at the time of the survey. The high discharge was the discharge in the Nenana River with a 100-year return interval. Output from each model was used to calculate pier scour. Contraction scour was calculated using only output from the one-dimensional model.

Water-surface profiles, pier- and contraction-scour estimates, and slough discharge simulated by the models were compared to determine the effectiveness of using a one-dimensional model to simulate two-dimensional flow. The models yielded similar pier scour estimates, but results in areas of two-dimensional flow, such as at the mouth of the Nenana River, varied considerably.

\section{Introduction}

Scour is a complex hydraulic process consisting of lowering a streambed by erosive forces. These forces are caused by acceleration of streamflow around obstructions or through channel contractions. Bridge scour is erosion of the streambed resulting from local flow accelerations caused by bridge piers, abutments, and, during extreme flows, the bridge structure and deck. According to Holnbeck and Parrett (1997), "the most common cause of bridge failure has historically been the scour or erosion of foundation material away from piers and abutments during large floods."

To address scour concerns, the Federal Highway Administration (FHWA) established a national bridge-scour program in 1991. The purposes of this program are to evaluate existing bridges for scour potential and to conduct research in scour-related areas (Holnbeck and Parrett, 1997). In 1994, the U.S. Geological Survey (USGS), in cooperation with the Alaska Department of Transportation and Public Facilities (ADOT\&PF) and the FHWA, began a cooperative study to analyze scour potential at bridges in Alaska. The initial phase of this project consisted of screening a large number of bridge sites for scour susceptibility using a one-dimensional hydraulic model at each bridge. Inputs for the models were derived from bridge plans provided by ADOT\&PF, along with other historical data. Methodology and results of this study are available in a report by Heinrichs and others (2001).

The USGS, in cooperation with the FHWA and ADOT\&PF, chose the Parks Highway crossing of Tanana River's main channel, near the town of Nenana, Alaska (fig. 1), for a further, in-depth study because the results of the phase 1 study indicated large scour potential. This site is hydraulically complicated. Streamflow in the Tanana River 


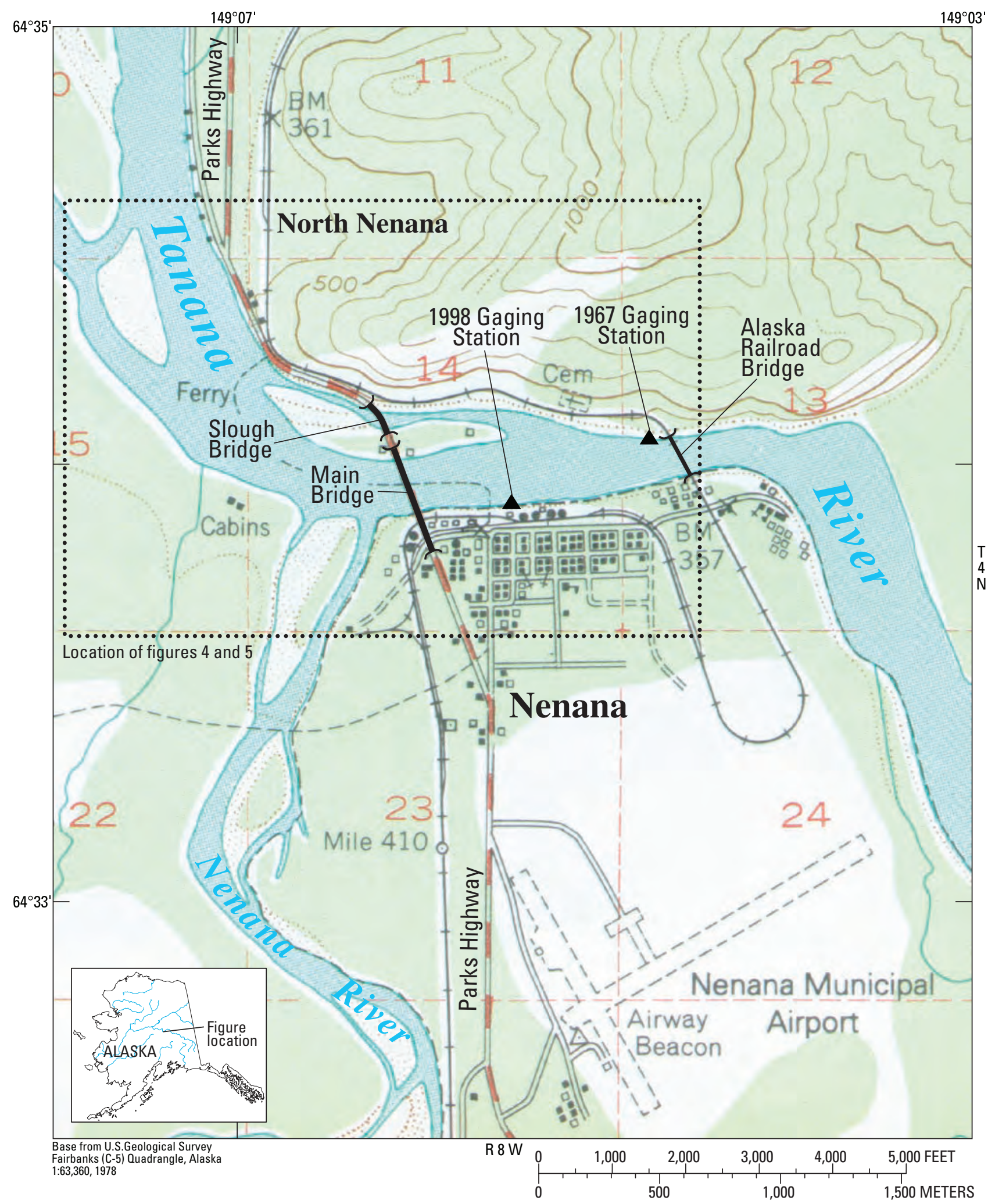

Figure 1. Location of the Parks Highway Bridge (Alaska Department of Transportation and Public Facilities Bridge \#201) scour-analysis site on the Tanana River at Nenana, Alaska, and the reach included in hydraulic models. 
at the site is divided between the main channel and a slough, and the Nenana River enters the Tanana River just downstream of the bridge. Tanana Slough re-enters the main channel downstream of the mouth of the Nenana River. Bridges cross both the main channel (ADOT\&PF bridge 201, referred to in this report as the main bridge) and the slough (ADOT\&PF bridge 202, referred to in this report as the slough bridge). The main bridge has a large pier, pier 3, that is oriented at an angle to streamflow. A one-dimensional hydraulic model used in phase 1 estimated a large scour value at the pier. Two types of scour were examined for the phase 2 study - contraction scour, caused by increased velocity in a reach where the flow area of the stream has been reduced, such as by bridge abutments or natural constrictions, and pier scour, erosion around piers caused by local flow acceleration and a resulting increase in turbulence (Richardson and Davis, 1995).

The primary concern at the Tanana bridge site is pier scour at pier 3 on the main bridge. Contraction scour is a secondary concern. Depth of pier scour is affected by several variables, including pier geometry, flow depth and velocity, and angle of attack. Pier geometry can be measured or taken from historical records such as bridge plans; flow depth and velocity can be measured or estimated with a computer model; and angle of attack must be estimated from visual observation or by using a two-dimensional model. In the phase 2 study, both one-dimensional and two-dimensional hydraulic models were used to simulate several discharge scenarios, to determine if a two-dimensional model might provide a better flow characteristic simulation. Hydraulics and scour estimates from each model were compared to each other to determine their applicability in studies at complex sites.

\section{Purpose and Scope}

This report (1) presents depths of pier scour, calculated using output from one-and two-dimensional hydraulic models, and contraction scour, calculated using output from the one-dimensional model for five discharge scenarios in the Tanana and Nenana Rivers; (2) documents construction and calibration of the hydraulic models; and (3) compares effectiveness of both types of hydraulic models in scour analyses at complex sites. Using both model types with the same geometry and flows will aid in choosing the correct approach to scour investigations at other complex sites.

The study required establishing and surveying 20 cross sections on the Tanana River, developing water-surface and top-of-bank profiles, and measuring discharge and velocity at each cross section. Historical discharge data were used to calibrate and run the hydraulic models. The one-dimensional model consisted of 43 cross sections, 20 surveyed cross sections, and 23 interpolated cross sections. The twodimensional model consisted of 8,198 nodes. The models simulated measured discharge for a large flood on the Tanana River and 100- and 500-year recurrence-interval flows on the Tanana River. Each flow was simulated with a high and a low discharge on the Nenana River.
The survey layout and setup of the models focused on accurately simulating high flows. This approach allowed larger spacing between cross sections and a coarser mesh for the two-dimensional model. Flow at the time of the survey was simulated to determine the applicability of the models to relatively low flows.

\section{Description of Study Area}

Tanana River is a glacially fed river with headwaters originating in the Alaska Range. The study reach includes the confluence with the Nenana River and extends from the Alaska Railroad Bridge to about 6,200 ft downstream of the highway bridge and about 1,600 ft up the Nenana River (fig. 1). Total length of the reach on the Tanana River main channel is about $10,000 \mathrm{ft}$.

As a glacially fed river, the Tanana has a distinctive hydrograph in which high summer flows begin with snowmelt runoff, but are sustained throughout the summer by glacial melt (fig. 2; Brabets and others, 2000). Extreme high flows result from rainfall and typically are in late summer. Flow in autumn and winter gradually decreases until snowmelt begins again in spring. Ice cover usually forms in October and the river remains frozen until spring breakup, usually in April or May. Breakup of the surface ice generally is caused by increased flow rather than melting in place.

As is common with glacially fed rivers, the sediment load of the Tanana River is quite high. A sediment sampling study in the late 1970s estimated annual sediment loads based on discharge records from USGS streamflow-gaging station Tanana River at Fairbanks (15485500) and on sediment samples taken near the gaging station and near the city of North Pole, Alaska (USGS site ID 644322147192900) (table 1, modified from Burrows and others, 1981). Average water-surface slope at the Fairbanks gaging station was

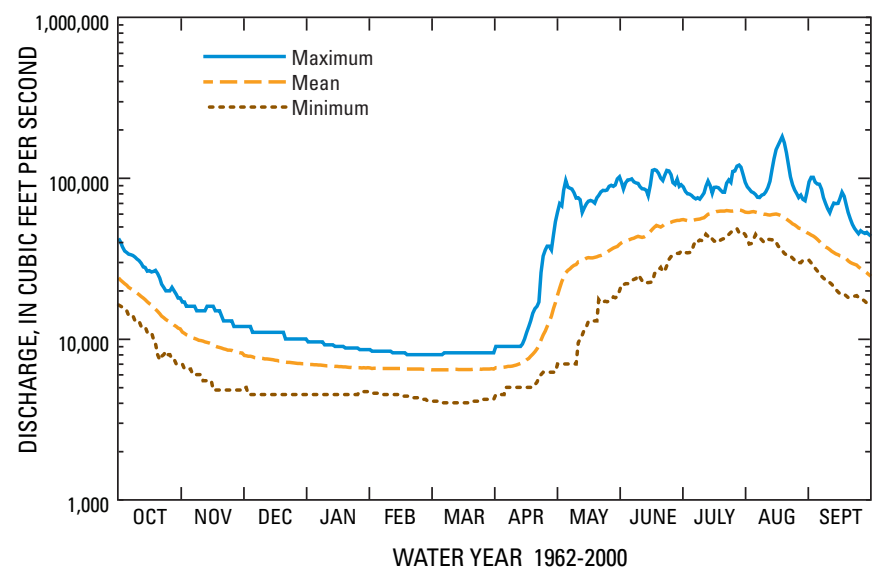

Figure 2. Maximum, mean, and minimum daily discharge for 38 years of record (1962-2000) for U.S. Geological Survey streamflow-gaging station 15515500, Tanana River at Nenana, Alaska. 
$0.00051 \mathrm{ft} / \mathrm{ft}$ and at the North Pole gaging station was $0.00118 \mathrm{ft} / \mathrm{ft}$ (Burrows and Harrold, 1983). These gaging station sites are about 60 river miles upstream of Nenana. Major tributaries between these sites include the Chena River (non-glacial, relatively low sediment load) and the Wood River (glacial, relatively high sediment load).

Bed-material samples were collected by the USGS at Tanana River at Nenana on June 7, 1964 (fig. 3). The average grain diameter in these samples ranged from less than 0.05 to $10 \mathrm{~mm}$. Average diameter of samples collected from Fairbanks and North Pole ranged from 0.12 to $34 \mathrm{~mm}$, depending on sampling site and location in the channel (Burrows and others, 1981). Bed-material size is closely tied to the water-surface slope. When the water surface is steeper, more energy is available for sediment transport and larger particles can be moved. The largest grain sizes were from the steepest site, North Pole. The water-surface slope at Nenana is about 0.0003 $\mathrm{ft} / \mathrm{ft}$. This is similar to the Fairbanks sampling site, in which average grain diameter for the composite of the channel was $0.23 \mathrm{~mm}$.

Table 1. Estimated annual sediment load of the Tanana River, Alaska, 1977-79.

[Modified from Burrows and others, 1981. Values are in million gallons per year. -, not available]

\begin{tabular}{|c|c|c|c|c|}
\hline \multirow{2}{*}{ Year } & \multicolumn{2}{|c|}{$\begin{array}{l}\text { Fairbanks } \\
\text { (15485500) }\end{array}$} & \multicolumn{2}{|c|}{$\begin{array}{c}\text { North Pole } \\
\text { (644322147192900) }\end{array}$} \\
\hline & Suspended & Bedload & Suspended & Bedload \\
\hline 1977 & $26,800,000$ & 326,000 & - & - \\
\hline 1978 & $21,200,000$ & 254,000 & $20,900,000$ & 274,000 \\
\hline 1979 & $27,500,000$ & 440,000 & $26,700,000$ & 369,000 \\
\hline
\end{tabular}

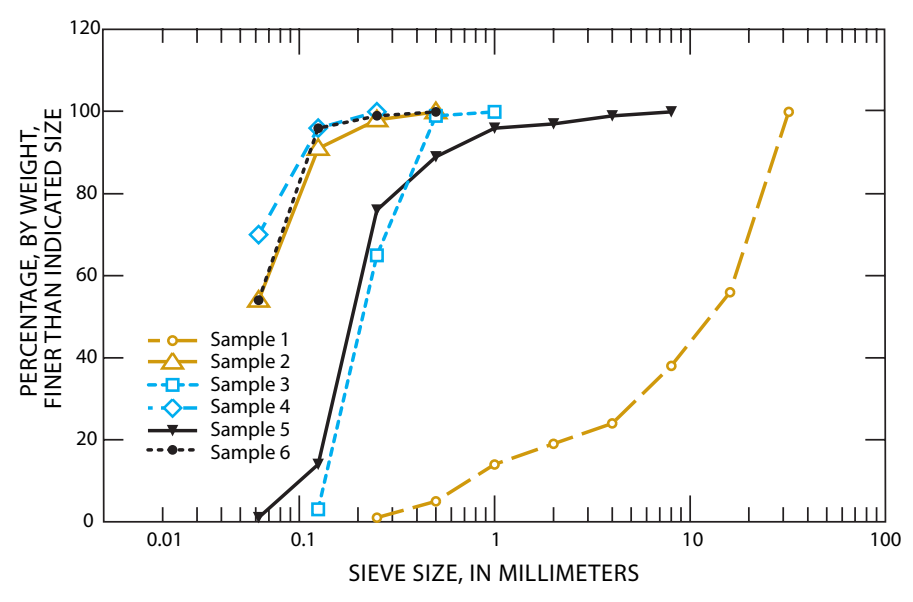

Figure 3. Grain-size distribution of bed-sediment samples collected by the U.S. Geological Survey from Tanana River at Nenana, Alaska, June 7, 1964.

\section{Hydraulic Modeling}

The U.S. Army Corps of Engineers' Hydrologic Engineering Center River Analysis System (HEC-RAS) model (Brunner, 1997) was used as the one-dimensional flow model for this project. This model is based on the standard step-backwater computation. It balances the energy equation from one cross section to the next. Energy losses between sections are from friction, expansion, and contraction. Friction losses are computed with Manning's equation. Expansion and contraction losses are determined by applying a coefficient to the change in velocity head. The model requires that the following assumptions are valid (Brunner, 1997):

- Flow is steady in time.

- Flow is gradually varied in space. This assumption is not required at hydraulic structures such as bridges or culverts because the momentum or other empirical equations can be used. HEC-RAS does the computations and can be set to use the most applicable method.

- Flow is one dimensional (velocity is always perpendicular with the cross section).

- Channel slope is less than 10 percent.

The two-dimensional model chosen for this project was RMA2 (Donnell and others, 2000) with the Surface Water Modeling System (SMS; Environmental Modeling Research Laboratory, 1999), a graphical user interface. RMA2 is a two-dimensional, depth-averaged, finite-element hydrodynamic numerical model (Donnell and others, 2000). The model solves for flow properties of two-dimensional elements, rather than for entire cross sections as does a onedimensional model. Depth-averaged velocity is computed in the $\mathrm{X}$ and $\mathrm{Y}$ horizontal directions. Velocities in the vertical (Z) direction are not accounted for and are assumed negligible. The model also assumes gradually varied sub-critical flow. Flow can be either steady (constant with time) or unsteady (varying with time). This program's computational procedure is based on the solutions of the Reynolds form of the NavierStokes equations for turbulent flows (Donnell and others, 2000). SMS is used as a pre- and post-processor, automating much of the set-up process for a finite-element network and providing various graphical outputs.

\section{Input Requirements}

Data requirements for one- and two-dimensional models are similar, except that a two-dimensional model requires more geometry information. One-dimensional models essentially require two-dimensional geometry data, whereas two-dimensional models require three-dimensional data. 
Both models require various additional information such as bridge geometry, bed roughness, and discharge. Water-surface profiles for a known discharge are used to calibrate each model type.

Two methods were used to survey channel geometry. Dry-land surface was surveyed with a total station using standard techniques. Channel geometry was surveyed with a vessel mounted acoustic Doppler current profiler (ADCP). This device uses sonar to measure water depth, vessel velocity in relation to the bed, and water velocity. Water-surface elevations were surveyed at each cross section. Twenty cross sections were surveyed using this method. Additional points along the banks between cross-sections also were surveyed for the two-dimensional model.

Bridge datum provided by ADOT\&PF was used for vertical datum. Horizontal coordinates were established at the downstream left-bank corner of the main bridge deck at N 10,000 ft, E 10,000 ft.

The roughness value in a one-dimensional model accounts for various factors that provide resistance to flow. These factors include (Arcement and Schneider, 1989):

- Basic bed-material roughness,

- Surface irregularities,

- Variation in cross section shape and size,

- Obstructions to the flow,

- Vegetation and flow conditions, and

- Meandering of the channel.

Channel roughness can be estimated using established techniques (Arcement and Schneider, 1989), or computed with a hydraulic model using surveyed water-surface elevations for a measured discharge. If roughness is determined with a hydraulic model, then all these factors affect the value. The difficulty with computing a roughness is that flood flows usually are quite different from surveyed flows. Higher flows can change bed geometry and are less affected by obstructions and small surface irregularities. Extreme flows may go over the banks, for which only estimated roughness is available. Less confidence can be placed in a model run at flows that vary greatly from the calibration discharge.

A two-dimensional model also relies on roughness values to compute energy loss. Similar factors apply, except that, because the model computes velocity in both $\mathrm{X}$ and $\mathrm{Y}$ directions, several factors do not affect the apparent roughness value. As noted above, roughness in a one-dimensional model accounts for factors such as channel meanders and flow that is not perpendicular to the cross sections. The two-dimensional model simulates the effect of these losses with non-perpendicular velocity, so they are not reflected in the roughness value. As a result, the roughness value used in the two-dimensional model often will be lower for the same conditions than the value used in the one-dimensional model.
Both model types require boundary conditions: a discharge and an initial water-surface elevation. Flow at this study site is sub-critical for all discharges; each model requires a discharge at the upstream boundary and a water-surface elevation at the downstream boundary. The six discharges used in the models were the discharge measured on August 19, 1998, the discharge measured during the flood on August 17, 1967, and floods with return intervals of 100 and 500 years on the Tanana River, with low and high discharges on the Nenana River (table 2). The Tanana River flood-frequency calculations were based on 32 years of record, 1962-94, at USGS streamflow-gaging station Tanana River at Nenana (15515500), using standard flood-frequency analyses (Interagency Advisory Committee on Water Data, 1982).

The only direct measurement of discharge at the mouth of the Nenana River was made on August 19, 1998. Discharges for the Nenana River for the other discharge scenarios were either estimated or determined as follows. Floods with return intervals of 100 and 500 years for the Nenana River were estimated using the regional regression flood estimates outlined in Jones and Fahl (1994). Nenana River discharge on August 17, 1967, was estimated at $30,800 \mathrm{ft}^{3} / \mathrm{s}$, based on the ratio between the computed 100- and 500-year floods at the mouth and those at streamflow-gaging station Nenana River at Healy (15518000). This ratio then was applied to the flow from the gage record for August 16, 1967, to determine discharge at the mouth for the models. Low discharge for Nenana River $\left(12,000 \mathrm{ft}^{3} / \mathrm{s}\right)$ was determined by rounding the measured discharge from the survey. High discharge was the computed 100-year flood at the mouth $\left(69,000 \mathrm{ft}^{3} / \mathrm{s}\right)$.

Table 2. Boundary conditions for discharge scenarios for the Tanana River at Nenana, Alaska, simulated using one- and two-dimensional hydraulic models.

[Discharge scenario: $Q_{100}$ (Nenana Low, High), calculated flood on Tanana River with return interval of 100 years and low, high discharge on Nenana River. $Q_{500}$ (Nenana Low, High), calculated flood on Tanana River with return interval of 500 years and low, high discharge on Nenana River. Discharge, Tanana Slough: Discharge determined by one-dimensional model (HEC-RAS, Hydrologic Engineering Center River Analysis System), two-dimensional model (RMA2, Resource Management Associates). Abbreviations: $\mathrm{ft}^{3} / \mathrm{s}$, cubic foot per second; $\mathrm{ft}$, foot]

\begin{tabular}{|c|c|c|c|c|c|}
\hline \multirow{4}{*}{ Discharge scenario } & \multicolumn{5}{|c|}{ Boundary conditions } \\
\hline & \multicolumn{4}{|c|}{ Discharge $\left(\mathrm{ft}^{3} / \mathrm{s}\right)$} & \multirow{3}{*}{$\begin{array}{l}\text { Initial water- } \\
\text { surface } \\
\text { elevation at } \\
\text { river station } 0 \\
\text { (ft) }\end{array}$} \\
\hline & \multirow{2}{*}{$\begin{array}{c}\text { Tanana } \\
\text { River }\end{array}$} & \multirow{2}{*}{$\begin{array}{c}\text { Nenana } \\
\text { River }\end{array}$} & \multicolumn{2}{|c|}{ Tanana Slough } & \\
\hline & & & HEC-RAS & RMA2 & \\
\hline August 19, 1998 & 42,700 & 11,800 & 3,680 & 1,800 & 343.7 \\
\hline August 17, 1967 & 171,000 & 30,800 & 13,300 & 13,400 & 352.9 \\
\hline $\mathrm{Q}_{100}$ (Nenana Low) & 162,000 & 12,000 & 11,600 & 11,500 & 351.6 \\
\hline (High) & 162,000 & 69,000 & 13,200 & 18,400 & 354.0 \\
\hline $\mathrm{Q}_{500}($ Nenana Low) & 203,000 & 12,000 & 16,200 & 14,900 & 353.4 \\
\hline (High) & 203,000 & 69,000 & 18,000 & 22,000 & 355.6 \\
\hline
\end{tabular}


Initial water-surface elevations either were known (at the surveyed discharge) or were estimated as the normal depth. Normal depths were computed using the water-surface slope from the discharge measurement made on August 17, 1967, and the roughness value from the calibrated model.

\section{Construction and Calibration of One-Dimensional Hydraulic Model}

Geometry for the one-dimensional model was a combination of surveyed and interpolated channel data and pier and abutment geometries from the as-built plans. The only bridge parts affecting flow characteristics are the piers and the south abutment of the main bridge. The other bridge abutments (the north one on the main bridge and both on the slough bridge) had little effect on the flow because they either are not in the water or do not project from the bank. The lowsteel elevations for the bridges are $389.58 \mathrm{ft}$ (main bridge) and $379.74 \mathrm{ft}$ (slough bridge). (Low steel is the lowest part of the bridge superstructure between supports over the river.) These are well above the water surface, even during extreme floods; the water-surface elevation on August 17, 1967, was $356.9 \mathrm{ft}$.

Twenty cross sections were surveyed for use in the one-dimensional model, but the model can better simulate expansions and contractions with additional sections.

HEC-RAS includes a routine that interpolates between cross sections to generate synthetic cross sections (Brunner, 1997). Channel geometry between the surveyed cross sections changed little, so the interpolation is valid through this reach. In all, 43 cross sections were used in the one-dimensional model analysis (fig. 4).

Once the geometry data were input to HEC-RAS, boundary conditions and discharges were entered to calibrate the model. Two discharges were used for model calibration: the discharge at the time of the survey on August 19, 1998, and the discharge measured on August 17, 1967. Four flooding situations were then modeled for the scour estimation. The 100- and 500-year recurrence-interval flows on the Tanana River were simulated with a high and a low discharge in the Nenana River. Simulated discharges and associated initial downstream water-surface elevations used as boundary conditions are summarized in table 2. Initial downstream water-surface elevation used with the discharge on August 19, 1998, was surveyed. Starting water-surface elevations for the other scenarios were estimated from the computed watersurface slope of the August 17, 1967, discharge measurement.

The model computed flow in the Tanana Slough using an iterative process beginning with an assumed flow division between the main channel and the slough. Water-surface elevations then were computed along each channel to the upstream junction. If the total energy head at the upstream cross section in each channel is equal, the flow division between channels is assumed to be correct. If they are not equal, the model changed the flow division and recomputed the water-surface profiles in the channels. Iterations continued until the total energy heads balanced.

The model was calibrated by running it with a given discharge having a known water-surface elevation and then adjusting the streambed roughness until the output closely matched the known elevation. Roughness can change with depth, so a calibration discharge near the magnitude of the flood discharge is desirable. The high-measurement discharge (August 17, 1967) was between the 100- and 500-year recurrence-interval flows, so the roughness was calibrated to this discharge (table 3 ).

The calibrated model was used to simulate four discharge scenarios on the Nenana River: the 100-year recurrenceinterval flow with both low and high flows and the 500year recurrence interval-flow with both low and high flows $\left(Q_{100} / 500\right.$, Nenana Low/High in table 2). Pier and contraction scour were computed using output from these scenarios, and the results were used to compare the one-dimensional model with the two-dimensional model.

Table 3. Material types and associated roughness values for the Tanana River at Nenana, Alaska.

[Abbreviations: RMA2, Resource Management Associates; HEC-RAS, Hydrologic Engineering Center River Analysis System; (lb/s)/ft ${ }^{2}$, pound per second per square foot; -, not applicable]

\begin{tabular}{|c|c|c|c|c|c|}
\hline \multirow{2}{*}{$\begin{array}{l}\text { Material type } \\
\text { description }\end{array}$} & \multicolumn{2}{|c|}{$\begin{array}{l}\text { RMA2 roughness } \\
\text { calibrated from } \\
\text { discharge }\end{array}$} & \multirow{2}{*}{$\begin{array}{l}\text { SMS eddy } \\
\text { viscosity } \\
{\left[(\mathrm{lb} / \mathrm{s}) / \mathrm{ft}^{2}\right]}\end{array}$} & \multicolumn{2}{|c|}{$\begin{array}{c}\text { HEC-RAS roughness } \\
\text { calibrated from } \\
\text { discharge }\end{array}$} \\
\hline & $\begin{array}{c}\text { Aug. 17, } \\
1967\end{array}$ & $\begin{array}{c}\text { Aug. 19, } \\
1998\end{array}$ & & $\begin{array}{c}\text { Aug. 17, } \\
1967\end{array}$ & $\begin{array}{c}\text { Aug. 19, } \\
1998\end{array}$ \\
\hline $\begin{array}{l}\text { Tanana River: } \\
\text { main channel }\end{array}$ & 0.023 & 0.015 & 100 & 0.0245 & 0.0245 \\
\hline $\begin{array}{l}\text { Tanana River: } \\
\text { slough }\end{array}$ & .040 & .022 & 45 & .037 & .037 \\
\hline Railroad yard & .045 & - & 20 & .045 & - \\
\hline Bridge abutment & .045 & - & 20 & .045 & - \\
\hline $\begin{array}{l}\text { Tanana and } \\
\text { Nenana } \\
\text { Rivers: bank }\end{array}$ & .045 & - & 20 & .045 & - \\
\hline $\begin{array}{l}\text { Nenana River: } \\
\text { main channel }\end{array}$ & .025 & - & 75 & .026 & .026 \\
\hline $\begin{array}{l}\text { Logjam at } \\
\text { mouth of } \\
\text { slough }\end{array}$ & .110 & .016 & 45 & .100 & .100 \\
\hline
\end{tabular}




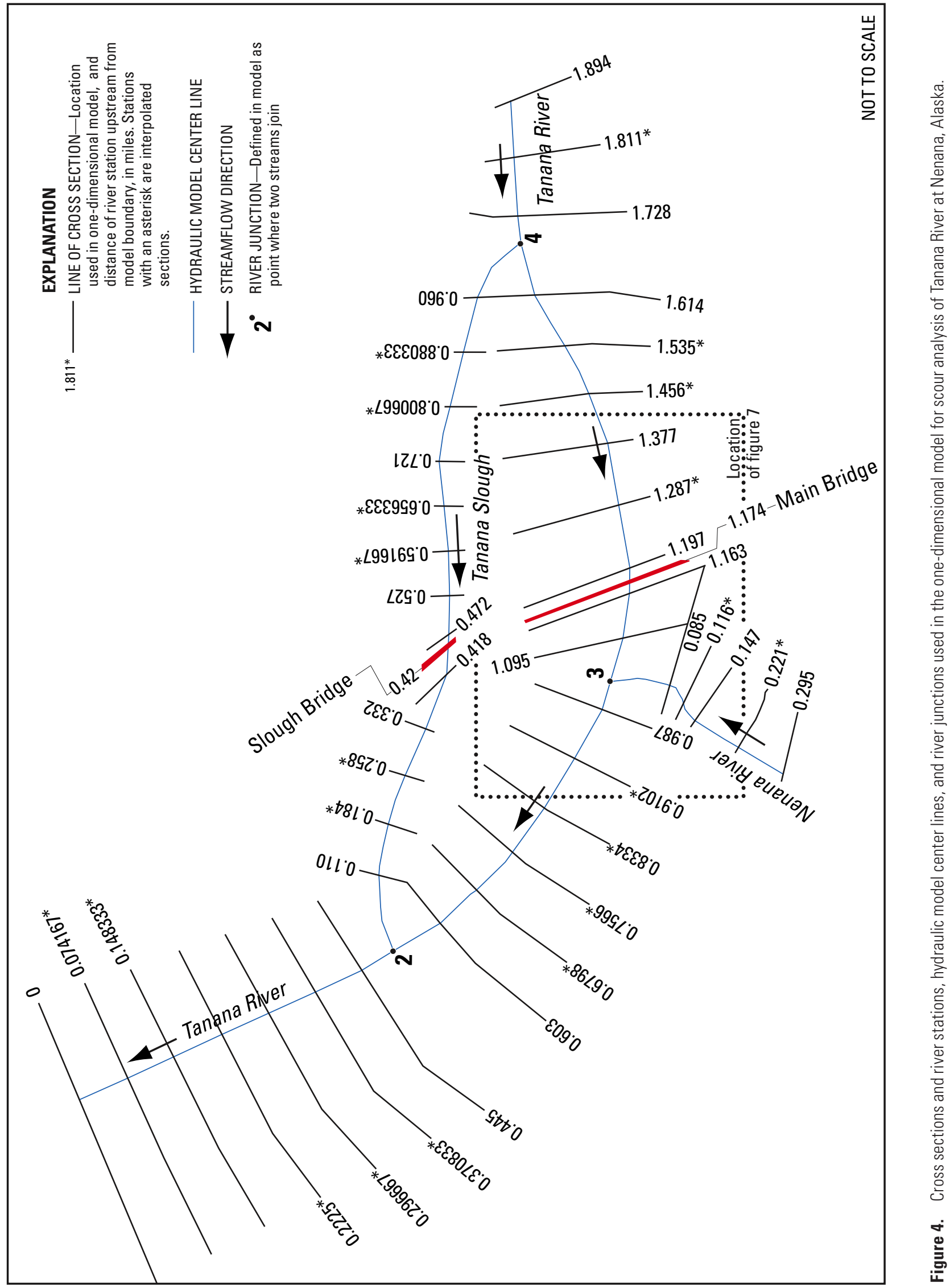




\section{Construction and Calibration of Two-Dimensional Hydraulic Model}

Surveyed cross sections were spaced too widely to create an adequate topographic map to run the RMA2 model, so 56 additional cross sections were interpolated from the surveyed cross sections by the HEC-RAS software. Interpolated cross sections, surveyed cross sections, and additional surveyed points along the banks were input to Computer Aided Drafting (CAD) software to add breaklines and boundaries to the data set. (Breaklines are where the simulated topographic surface slope is allowed to change abruptly. For example, the top of a cut bank. A boundary is a line defining the edge of the data.) The data set then was exported into SMS.

The next step in setting up the two-dimensional model was to generate a computational mesh (fig. 5). The mesh consisted of triangular and quadrilateral elements that cover the entire simulated area. A well-designed mesh will increase model stability. Properties of a well designed mesh are discussed in Donnell and others (2000).

Elevations and material properties then were assigned to the mesh nodes. Elevations were assigned by overlaying the mesh with the geometry data set. SMS interpolates elevations for nodes that do not reside directly over a known point. Roughness and eddy viscosity were assigned to each element. Roughness was entered as a Manning's $n$, but, as discussed earlier, the value for the two-dimensional model tends to be lower than the value for a one-dimensional model. Eddy viscosity is a term used to define the effect that velocity in one element will have on adjacent elements. Eddy viscosity and roughness values were defined as properties of a specific material type. Each element in the mesh was then given a material type (table 3 ). This allowed the modeler to rapidly change the properties of all similar material types during calibration runs.

Boundary conditions are defined by assigning flow to the upstream model boundaries and a water-surface elevation to the downstream boundaries. The two-dimensional model used two upstream boundaries (Tanana River and Nenana River) and one downstream boundary (Tanana River below the confluence). Discharges and downstream water surfaces for this model were the same as was used for the HEC-RAS model (table 2).

Model calibration begins with selecting a tolerance level for the change in water-surface elevations between computational iterations. When this tolerance level is met, the model has converged on a solution. The two-dimensional model was considered converged when the change was less than $0.1 \mathrm{ft}$. Increasing eddy viscosity causes the model to converge more easily, but a value that is too high causes the velocity vectors to be parallel and the model to appear onedimensional. Values used with this model were the lowest that would result in model convergence. Eddy viscosities ranged from 20 to $100(\mathrm{lb} / \mathrm{s}) / \mathrm{ft}^{2}$ (table 3), which are well within the range of the 0.2 to $1,000(\mathrm{lb} / \mathrm{s}) / \mathrm{ft}^{2}$ suggested by Donnell and others (2000).
The model was calibrated using the measured discharges (August 19, 1998, and August 17, 1967) and their associated water-surface elevations. The model divided flow between the main channel of the Tanana River and the slough. Changing the roughness in the main channel of the Tanana River varied the simulated water-surface elevation. The simulated flow division was varied by changing the roughness of the slough channel and a logjam at the upper end of the slough. Values used to calibrate the two-dimensional model are presented in table 4, and a comparison of water-surface profiles simulated by the one- and two-dimensional models is presented in figure 6A. Different roughness values were required for low and high discharge in the two-dimensional model. The survey data and mesh design were developed to optimize model use for high flows. As a result, the model did not perform well simulating low discharges. Channel roughness used in the low discharge simulation is lower than that used in the high-discharge scenarios. Roughness was reduced to offset the affects of using a coarse mesh designed for the high-flow simulations. Roughness was reduced to account for ragged edges of coarse high-flow mesh and to accommodate a decreased flow area produced by turning off edge elements to increase model stability. To accurately simulate low discharge conditions, a denser topographic data set would have to be gathered and a finer computational mesh built.

Once the model was calibrated, runs were made with the five discharge scenarios that represent floods (table 2). Results from these simulations were used to determine flow depths and angles of attack for input to the scour calculations. The results show definite areas of two-dimensional flow that cannot be described with the one-dimensional model.

Table 4. Values used to calibrate the two-dimensional hydraulic model for the Tanana River at Nenana, Alaska.

[Abbreviations: $\mathrm{ft}$, foot; $\mathrm{ft}^{3} / \mathrm{s}$, cubic foot per second]

\begin{tabular}{|c|c|c|c|c|}
\hline \multirow{2}{*}{$\begin{array}{l}\text { Calibration } \\
\text { parameter }\end{array}$} & \multicolumn{2}{|c|}{$\begin{array}{l}\text { High flow, } \\
\text { Aug. 17, } 1967\end{array}$} & \multicolumn{2}{|c|}{$\begin{array}{l}\text { Low flow, } \\
\text { Aug. 19, } 1998\end{array}$} \\
\hline & Measured & Modeled & Measured & Modeled \\
\hline $\begin{array}{l}\text { Water-surface } \\
\text { elevation at } \\
\text { streamflow-gaging } \\
\text { station (ft) }\end{array}$ & ${ }^{1} 356.9$ & 356.9 & ${ }^{2} 346.5$ & 346.2 \\
\hline $\begin{array}{l}\text { Discharge through } \\
\text { main channel } \\
\left(\mathrm{ft}^{3} / \mathrm{s}\right)\end{array}$ & 158,000 & 158,000 & 38,400 & 41,200 \\
\hline $\begin{array}{l}\text { Discharge through } \\
\text { slough }\left(\mathrm{ft}^{3} / \mathrm{s}\right)\end{array}$ & 13,300 & 13,400 & 4,200 & 1,800 \\
\hline
\end{tabular}

${ }^{1}$ Streamflow-gaging station 15515500 at 1967 location.

${ }^{2}$ Streamflow-gaging station 15515500 at 1998 location. 


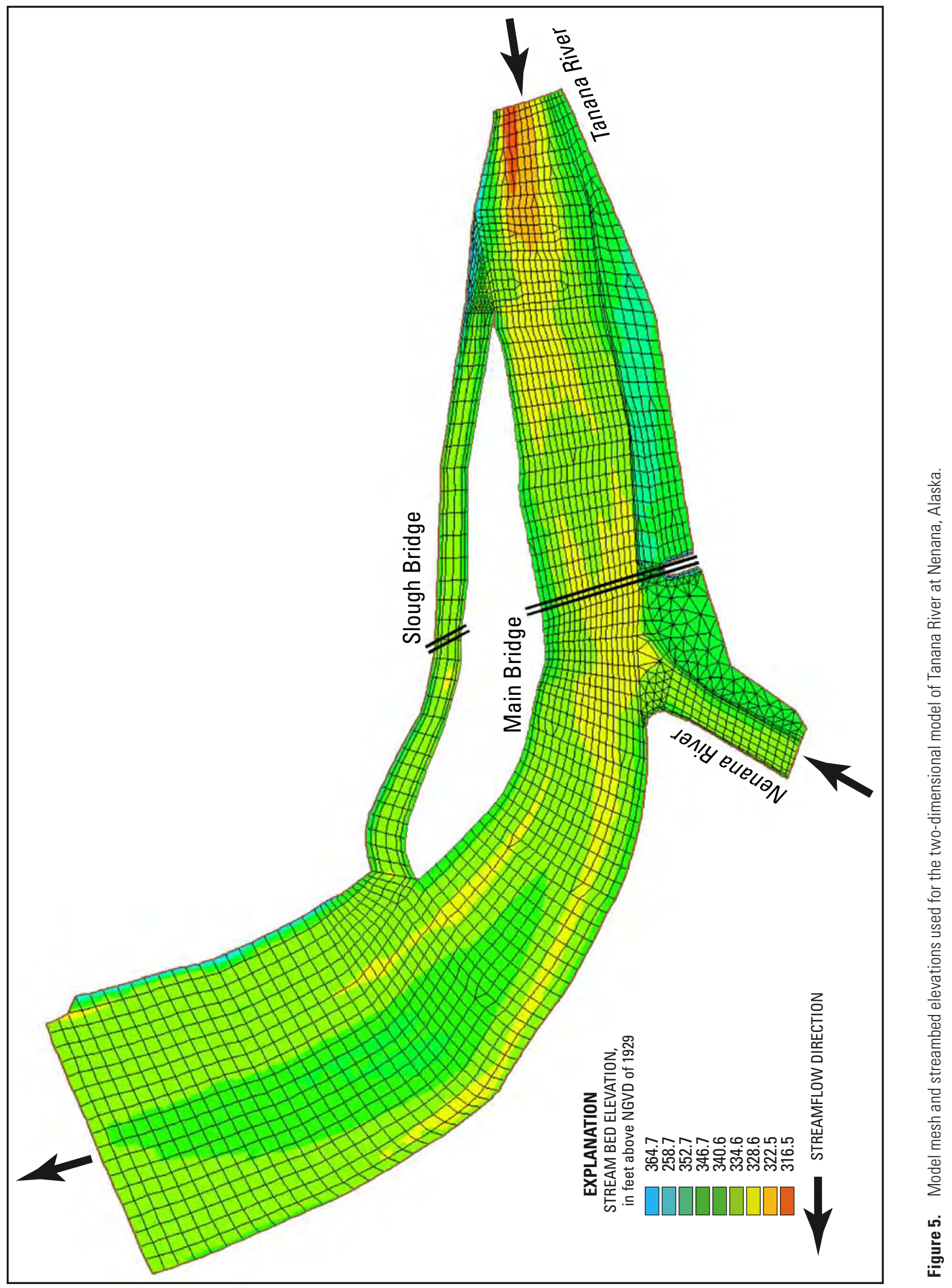




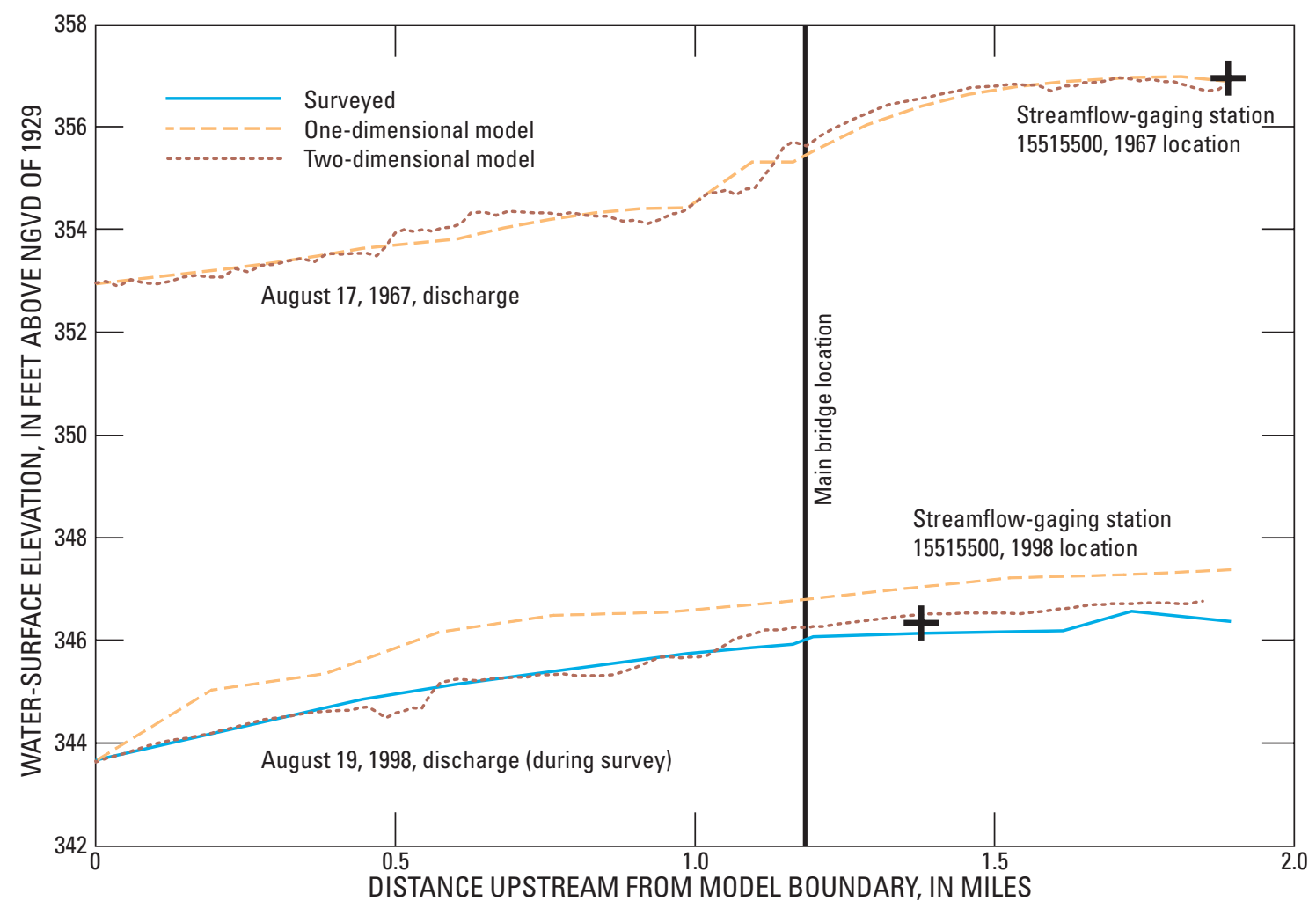

\section{A. DISCHARGE SCENARIOS FOR CALIBRATION}

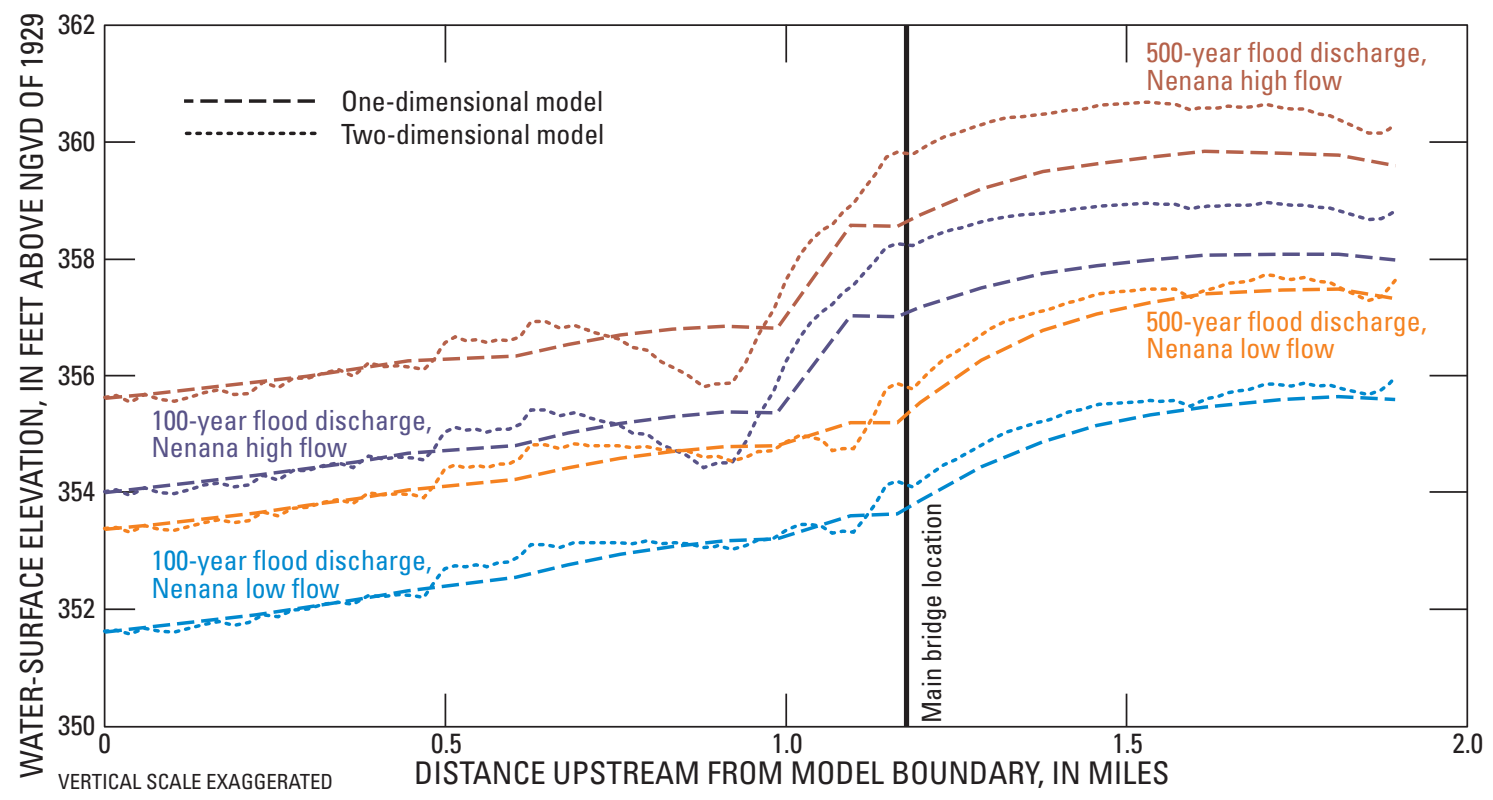

\section{B. DISCHARGE SCENARIOS FOR 100- AND 500-YEAR FLOODS WITH LOW AND HIGH FLOW IN NENANA RIVER}

Figure 6. Water-surface profiles for six discharge scenarios on Tanana River at Nenana, Alaska, simulated using one- and two-dimensional hydraulic models.

River stationing is along center of channel from downstream to upstream. 


\section{Scour Calculations}

Two forms of scour studied at the main pier on the bridge crossing the main channel of the Tanana River were contraction scour and pier scour. The primary concern is pier scour, which was calculated using the one- and twodimensional models for the five high discharge scenarios. Contraction scour was calculated using output from the one-dimensional model. Because contraction scour was not of primary concern and was of minimal magnitude, the two-dimensional model was not used to further evaluate contraction.

Procedure and scour estimation equations used in this analysis are described in "Evaluating Scour at Bridges; 3d ed." (Richardson and Davis, 1995). This publication is also known as HEC-18, and describes the scour estimation methods used by FHWA.

\section{Contraction Scour}

Contraction scour was calculated with the live-bed equation from HEC-18 (Richardson and Davis, 1995). Sediment samples taken at Fairbanks by Burrows and others (1981) show that the Tanana River carries a considerable bed load during all stages; the same can be inferred for the Nenana River. This means that the bed is always 'live'. Contractionscour calculation results from the HEC-RAS models and variables used in the calculations are shown in table 5.

\section{Pier Scour}

Pier scour was calculated using the methods in HEC-18 (Richardson and Davis, 1995) and hydraulic data output from both the one- and two-dimensional models. The equation is applicable to both live-bed and clear-water scour conditions. Input variables from both models are in table 5.

Angle of attack can make a significant difference in the calculated pier scour. Partly for this reason, the twodimensional model was used. The estimated angle of attack from the discharge measurement of August 17, 1967, was used for the one-dimensional model pier scour calculations. The angles of attack simulated by the two-dimensional model (table 5) were used for the calculations with two-dimensional data. The two-dimensional model demonstrated that the angle of attack is affected by discharge in the Nenana River.

The one-dimensional model divided the channel into 20 subsections of equal conveyance. Depth and velocity for the calculation can be taken from directly upstream of the pier or from the deepest, fastest channel subsection. The subsectioning is based on the assumption that flow is evenly distributed across the channel. If this is not the case, then the depth and velocity values could be in error.

The two-dimensional model calculated the depths and velocities at many points across the channel, so the values just upstream of the pier are presumed to be more reliable. The values directly upstream of the pier were used to calculate pier scour for both models. This does not give the most conservative answer, but did provide a basis for comparison of the models.

Table 5. Calculated depths of pier scour, contraction scour, and angles of attack at pier 3, and associated variables, Tanana River at Nenana, Alaska.

[Abbreviations: HEC-RAS, Hydrologic Engineering Center River Analysis System; RMA2, Resource Management Associates; ft, foot; ft/s, foot per second; $\mathrm{ft} / \mathrm{s}^{2}$, foot per square second; $\mathrm{ft}^{3} / \mathrm{s}$, cubic foot per second]

Pier Scour calculated using output from one-dimensional HEC-RAS model

$\frac{y_{p s}}{y_{1}}=2.0 K_{1} K_{2} K_{3}\left(\frac{a}{y_{1}}\right)^{0.65} F r^{0.43}$

Velocity at nose of pier ( $\mathrm{ft} / \mathrm{s})$

Depth at nose of pier (ft/s)

Gravity constant $\left(\mathrm{ft} / \mathrm{s}^{2}\right)$

Froude number at nose of pier

Pier shape

Pier shape correction factor

Angle of attack (degree)

Pier width (ft)

Pier length (ft)

Ratio

Angle of attack correction factor

Pier Scour (ft)
Discharge scenario

\begin{tabular}{|c|c|c|c|c|}
\hline \multirow{2}{*}{$\begin{array}{c}\text { Discharge, } \\
\text { Aug. 17, } \\
1967\end{array}$} & \multicolumn{2}{|c|}{ 100-year flood } & \multicolumn{2}{|c|}{ 500-year flood } \\
\hline & Low flow & High flow & Low flow & High flow \\
\hline 10.51 & 10.81 & 8.90 & 12.21 & 10.23 \\
\hline 21.3 & 19.6 & 22.9 & 21.3 & 24.5 \\
\hline 32.17 & 32.17 & 32.17 & 32.17 & 2.2 \\
\hline .40 & .43 & .33 & .47 & .36 \\
\hline Sharp nose & Sharp nose & Sharp nose & Sharp nose & Sharp nose \\
\hline 1.0 & 1.0 & 1.0 & 1.0 & 1.0 \\
\hline 15 & 15 & 15 & 15 & 15 \\
\hline 14.0 & 14.0 & 14.0 & 14.0 & 14.0 \\
\hline 62 & 62 & 62 & 62 & 62 \\
\hline 4 & 4 & 4 & 4 & 4 \\
\hline 1.6 & 1.6 & 1.6 & 1.6 & 1.6 \\
\hline 37.8 & 37.9 & 35.6 & 40.3 & 38.1 \\
\hline
\end{tabular}


Table 5. Calculated depths of pier scour, contraction scour, and angles of attack at pier 3, and associated variables, Tanana River at Nenana, AlaskaContinued

[Abbreviations: HEC-RAS, Hydrologic Engineering Center River Analysis System; RMA2, Resource Management Associates; ft, foot; ft/s, foot per second; $\mathrm{ft} / \mathrm{s}^{2}$, foot per square second; $\mathrm{ft}^{3} / \mathrm{s}$, cubic foot per second]

Pier Scour calculated using output from two-dimensional RMA2 model

$\frac{y_{p s}}{y_{1}}=2.0 K_{1} K_{2} K_{3}\left(\frac{a}{y_{1}}\right)^{0.65} F r^{0.43}$
Discharge scenario

\begin{tabular}{cccccc}
\hline $\begin{array}{c}\text { Discharge, } \\
\text { Aug. 17, } \\
\text { 1967 }\end{array}$ & \multicolumn{2}{c}{ Low flow } & High flow & & \multicolumn{2}{c}{ Low flow } & Low & Loar flood & High flow \\
\cline { 5 - 6 } \cline { 5 - 6 }-10.93 & -11.23 & -8.82 & & -12.68 & -10.20 \\
-1.42 & -1.72 & -0.84 & & -1.83 & -0.98 \\
11.02 & 11.36 & 8.86 & & 12.81 & 10.25 \\
23.9 & 22.4 & 26.5 & & 24.1 & 28.0 \\
32.17 & 32.17 & 32.17 & & 32.17 & 32.2 \\
.40 & .42 & .30 & .46 & .34
\end{tabular}

Sharp nose Sharp nose Sharp nose Sharp nose Sharp nose

Pier shape correction factor

Angle of flow (degree)

1

263

248

Angle of attack (degree)

Pier width (ft)

Pier length (ft)

Ratio

Angle of attack correction factor

Bed condition (dunes) correction factor

Pier Scour (ft)
$K_{1}$

AA

a

$v_{\mathrm{x}}$
$v_{\mathrm{y}}$
$v_{1}$
$y_{1}$
$\mathrm{~g}$
$F r=v_{\mathrm{l}} /\left(g y_{1}\right)^{1 / 2}$
$K_{1}$

L

L/a

$K_{2}=f(A A, L / a)$

$K_{3}$

$\mathbf{y}_{\text {ps }}$

1.0
261
248

13

14.0

62

4

1.5

1.1

38.0

1.0
265
248

17

14.0

62

4

1.6

1.1

38.9
1.6
37.3

$\begin{array}{cc}1.0 & 1.0 \\ 262 & 265 \\ 248 & 248 \\ 14 & 17 \\ 14.0 & 14.0 \\ 62 & 62 \\ 4 & 4 \\ 1.5 & 1.6 \\ 1.1 & 1.1 \\ \mathbf{4 0 . 8} & \mathbf{4 0 . 0}\end{array}$

Live-bed contraction scour simulated using output from one-dimensional HEC-RAS model

$$
\begin{aligned}
& \frac{y_{2}}{y_{1}}=\left(\frac{Q_{2}}{Q_{1}}\right)^{\frac{6}{7}}\left(\frac{W_{1}}{W_{2}}\right)^{K_{1}} \\
& y_{c s}=y_{2}-y_{1}=\text { (average scour depth) }
\end{aligned}
$$

\section{Discharge scenario}

$$
\text { 100-year flood }
$$

500-year flood

Discharge,

\begin{tabular}{|c|c|c|c|c|c|c|}
\hline Total discharge in Tanana River main channel $\left(\mathrm{ft}^{3} / \mathrm{s}\right)$ & Q & 158,000 & 150,000 & 149,000 & 187,000 & 185,000 \\
\hline Exponent determined from mode of bed material transport & $K_{1}$ & 69 & 69 & .69 & 69 & .69 \\
\hline Discharge in main channel of approach section $\left(\mathrm{ft}^{3} / \mathrm{s}\right)$ & $Q_{1}$ & 156,700 & 148,000 & 142,000 & 180,600 & 173,700 \\
\hline Discharge in main channel of contracted (bridge) section $\left(\mathrm{ft}^{3} / \mathrm{s}\right)$ & $Q_{2}$ & 155,800 & 148,100 & 143,400 & 182,200 & 176,600 \\
\hline Width of main channel of approach section (ft) & $W_{1}$ & 796 & 796 & 796 & 796 & 796 \\
\hline Width of main channel of contracted (bridge) section (ft) & $W_{2}$ & 706 & 706 & 710 & 706 & 710 \\
\hline Average depth of main channel of approach section (ft) & $y_{1}$ & 20.7 & 19.1 & 22.2 & 20.9 & 23.8 \\
\hline
\end{tabular}

Aug. 17, 1967 Low flow High flow Low flow High flow 


\section{Comparison of Models}

Water-surface profiles from each model are shown in figure 6. The water-surface elevations from RMA2 are from the approximate center of the main channel. Those from HECRAS are the average water surface from each cross section. The largest difference in the profiles was less than $1.5 \mathrm{ft}$, just downstream of the main bridge (at 1.18 mi upstream of the downstream boundary), where the models are affected most by the two-dimensional nature of the flow. The difference between the models is much greater when the discharge in the Nenana River is high (fig. 6B).

When the Nenana River has relatively low discharge and the Tanana River discharge is high, the flow in the main channel of the Tanana River appears as parallel velocity vectors in the two-dimensional model (figs. 7A, 7C). When the Nenana River discharge is high, the velocity vectors indicate that it forces flow in the Tanana River to cross the channel from left to right (figs. $7 B, 7 D$ ). Once the flow vectors return to mainly parallel at about 0.75 mi upstream of the downstream boundary, the two models match reasonably well. The difference in flow patterns at the convergence of the channels between the models with low and high flow in the Nenana River is shown in figure 7.

The profiles show some variation in the reach upstream of the bridge (fig. $6 \mathrm{~B}$ ). RMA2 computed a larger backwater effect from the increased discharge in the Nenana River.
When the Nenana River is low and the flow is mostly onedimensional, then the RMA2 and HEC-RAS profiles are quite similar (fig. 6B).

Comparing the flows in Tanana Slough also demonstrates the difference in backwater simulated by each model (fig. 8). Simulations were similar for scenarios with low discharge in the Nenana River, but RMA2 simulated considerably more flow in the slough for scenarios with high discharge in the Nenana River.

Pier-scour depth calculated using output from the two-dimensional model was slightly greater than that using the output from the one-dimensional model, because the two-dimensional model computed slightly different angles of attack than were used in the one-dimensional model calculations (fig. 9). Differences in values were less than 6 percent and were negligible.

Streamflow velocities along the cross section at river mile 1.377, measured on August 19, 1998, and calculated from each model type also were used to compare the models (fig. 10). Velocities for 1998 were measured with a Price AA current meter using standard USGS methods (Buchanan and Somers, 1969). Velocities calculated from the two-dimensional model are the total velocity magnitude. Flow direction at this cross section is perpendicular to the cross section, so neither velocity data set was adjusted for angles. Velocity calculated from the one-dimensional model is the average velocity for the cross section. Velocities from all three sources match well. 


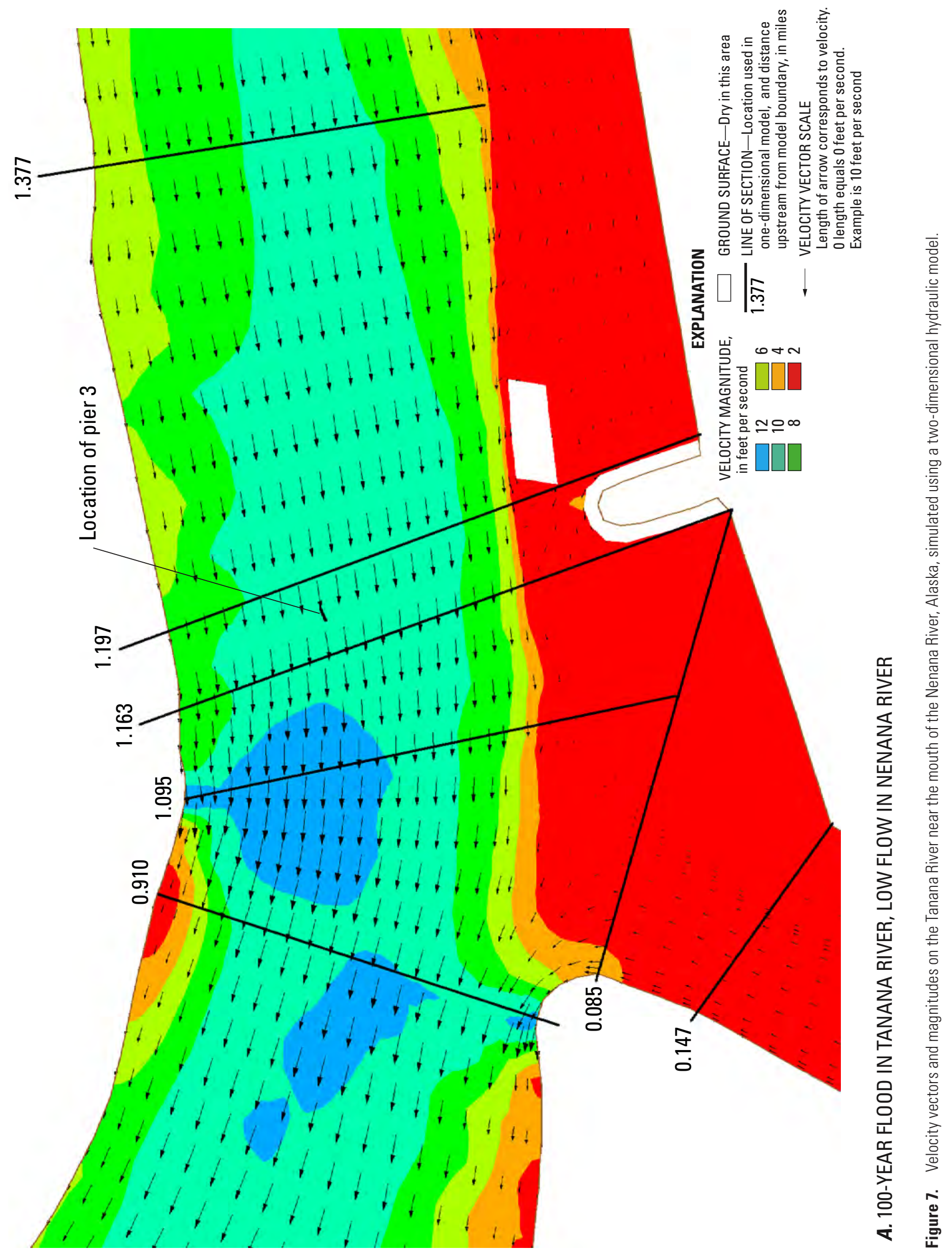



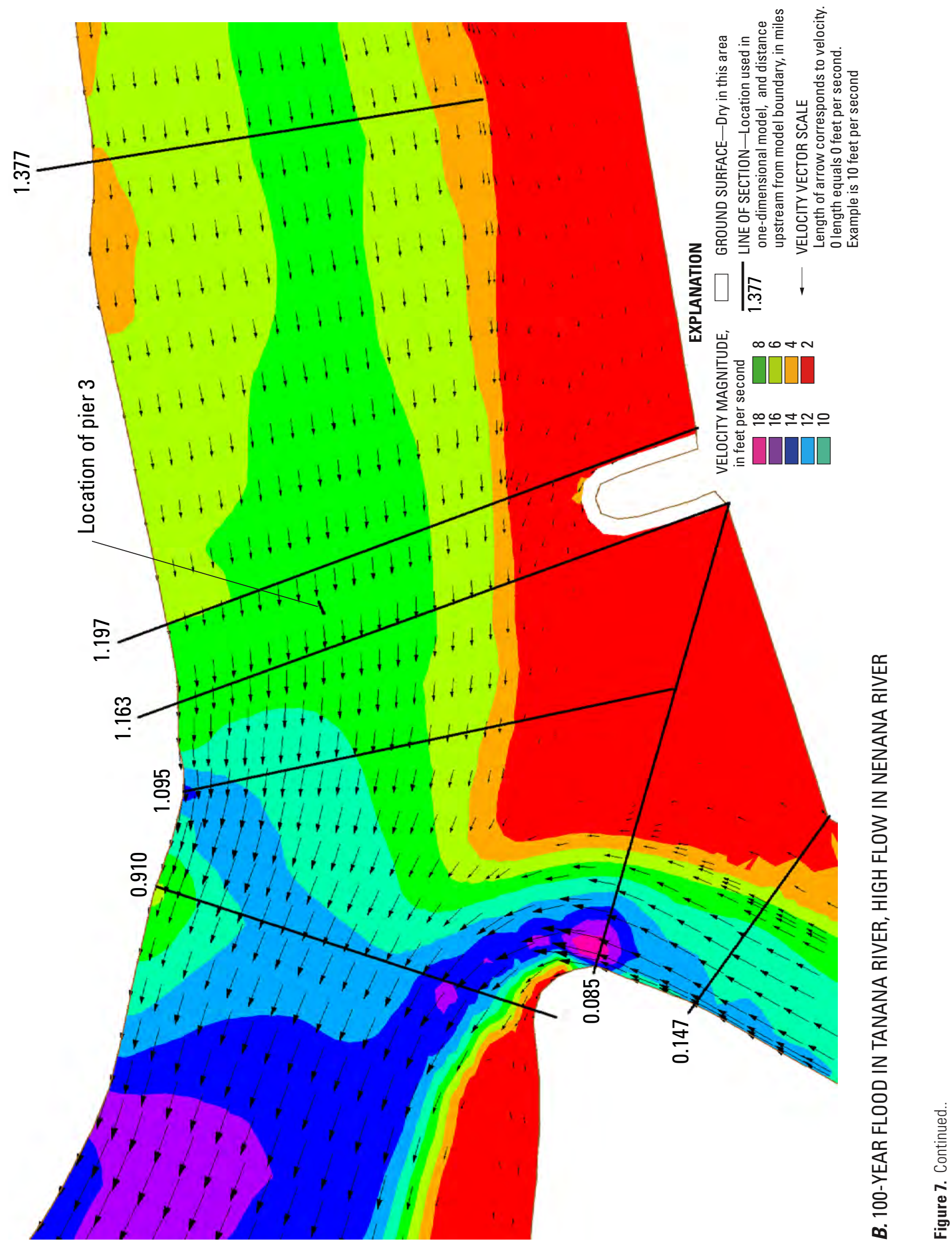


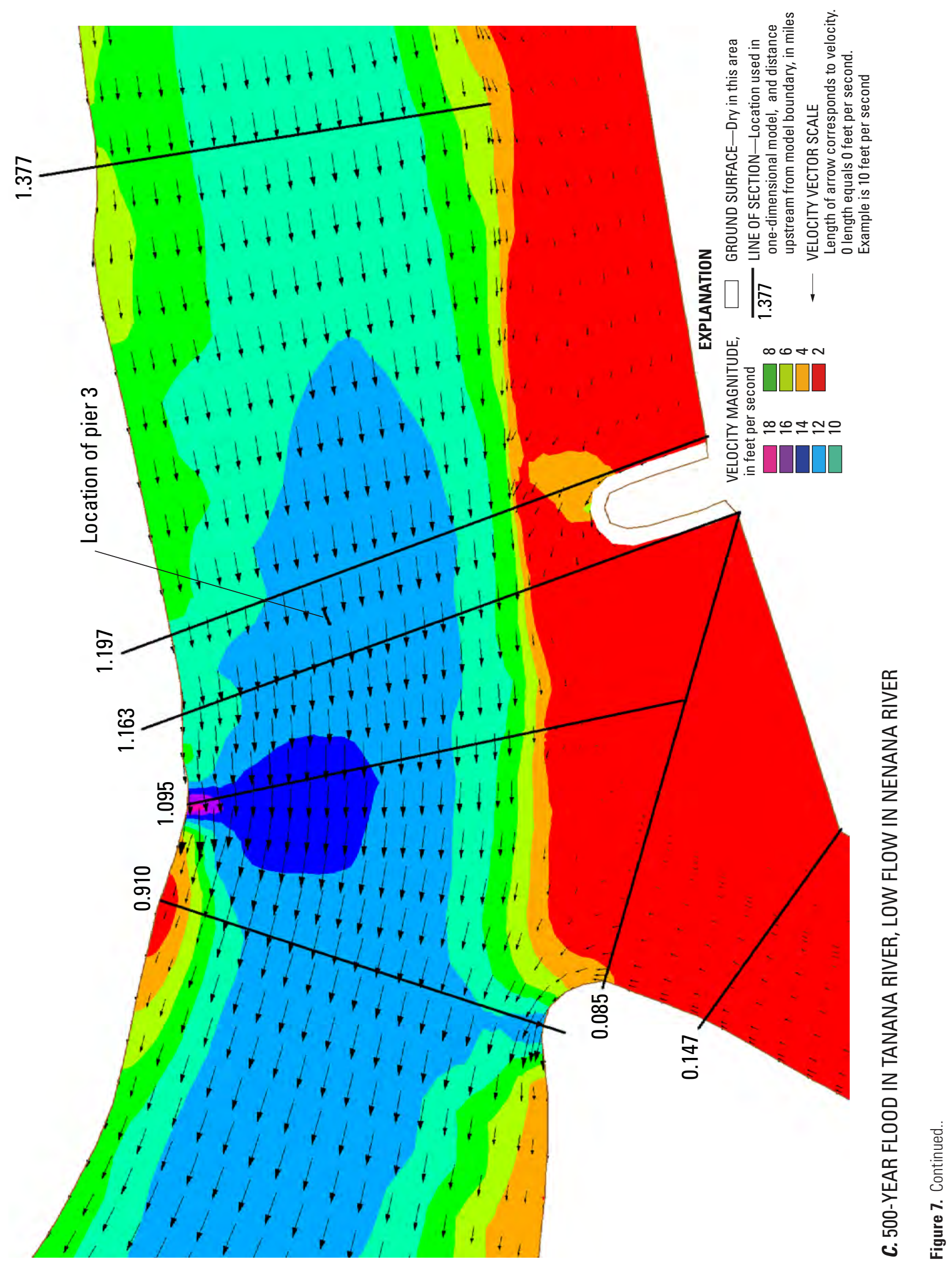




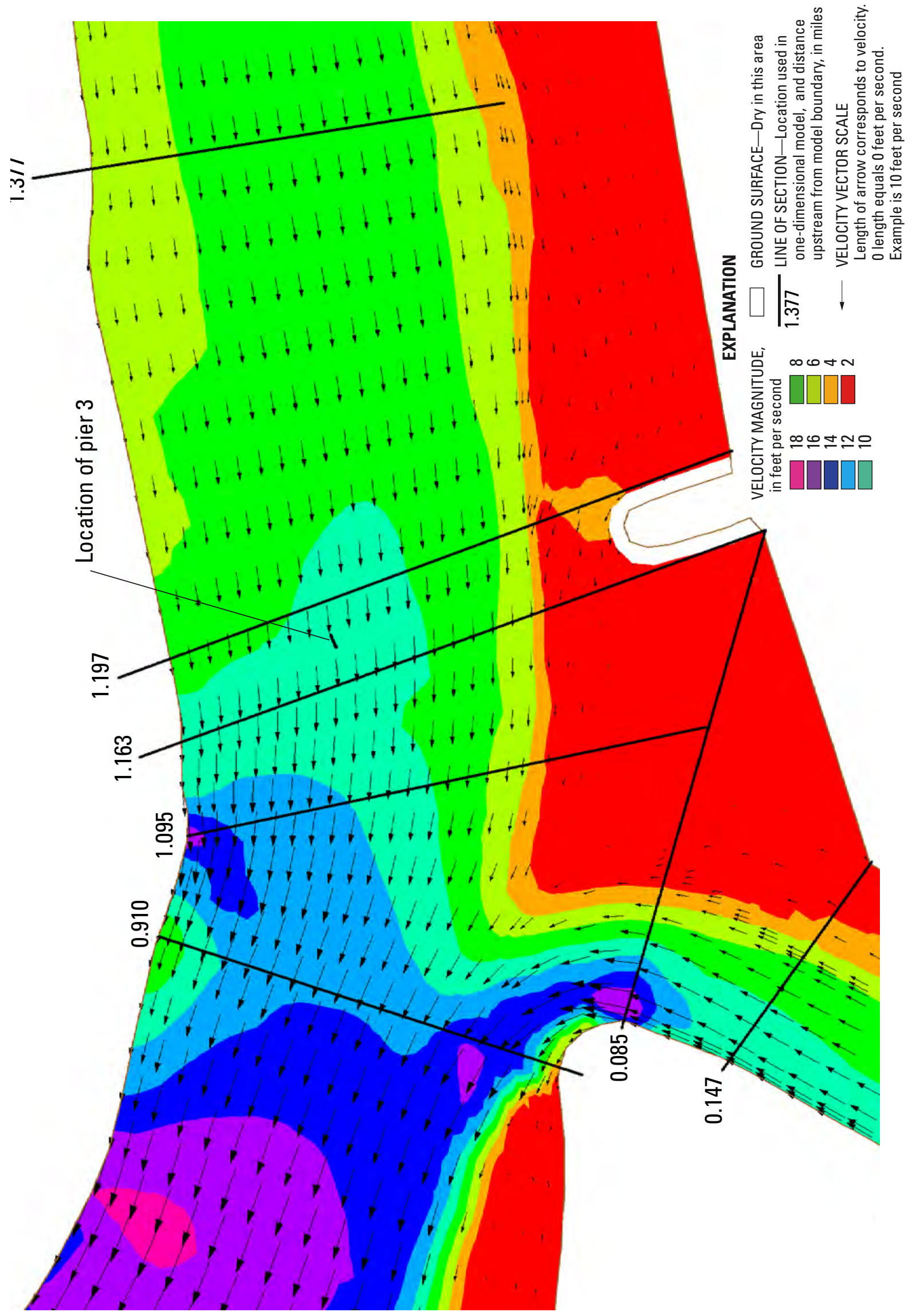

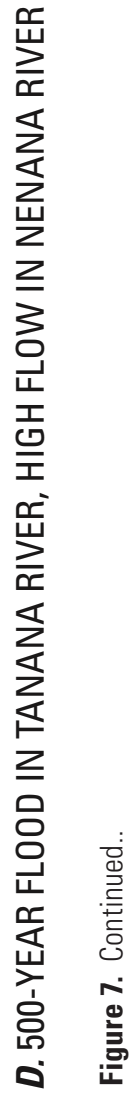




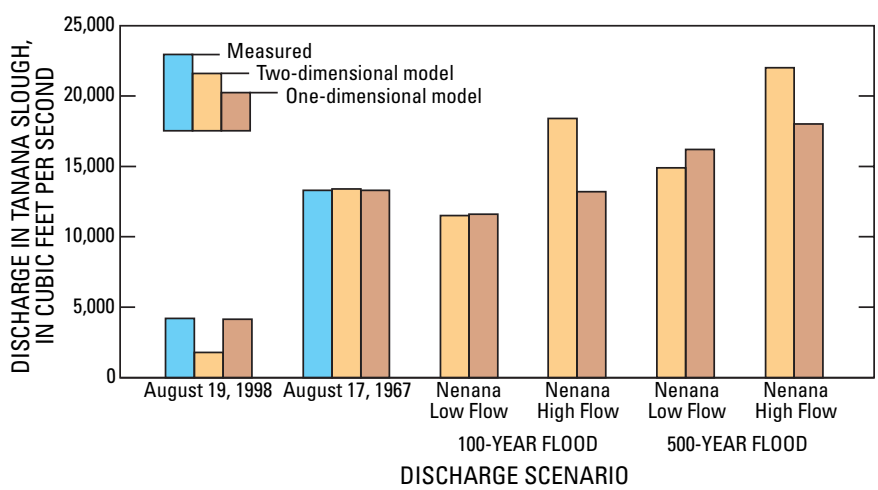

Figure 8. Comparison of discharge in Tanana Slough for six discharge scenarios simulated using one- and two-dimensional hydraulic models.

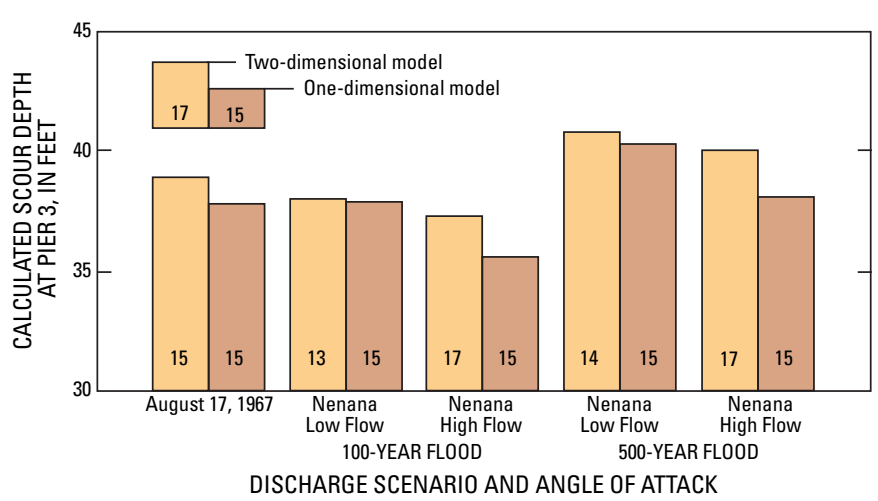

Figure 9. Depth of pier scour, calculated using output from oneand two-dimensional hydraulic models, and angle of attack at bridge pier 3 for five discharge scenarios representing floods on the Tanana River near Nenana, Alaska.

See table 5 for values.

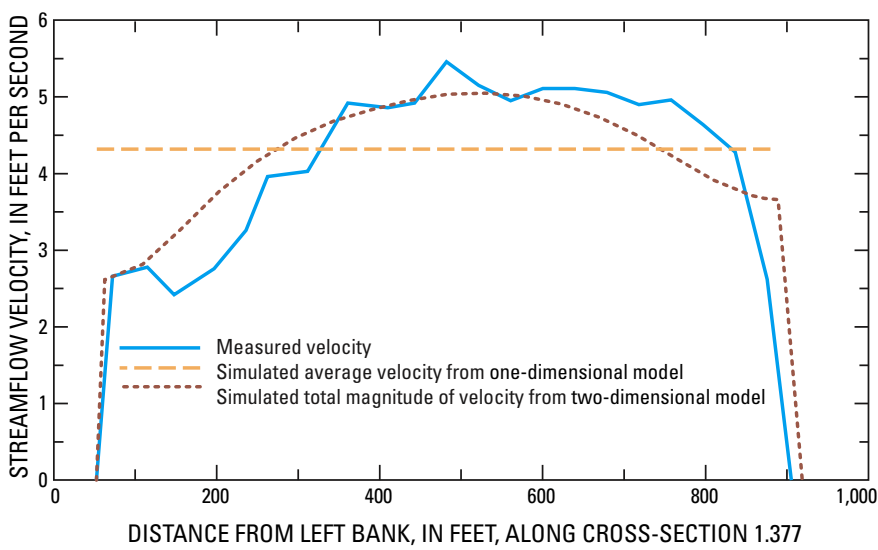

Figure 10. Streamflow velocity along cross-section 1.377 on the Tanana River near Nenana, Alaska, measured on August 19, 1998, and simulated using one- and two-dimensional hydraulic models. Discharge for August 19, 1998, was 42,700 cubic feet per second.

\section{Summary and Conclusions}

Parks Highway Bridge at Nenana, Alaska, crosses a hydraulically complex reach of the Tanana River. The Tanana River is divided into two channels, the main channel and the slough channel, and both are crossed by bridges. The Nenana River enters the main channel several hundred feet downstream of the bridge and affects flow at the bridge crossing. A large pier at the bridge over the main channel is at an angle to the flow.

This site was selected for a comprehensive scour assessment that included a test case for a two-dimensional hydraulic model because of the site's complexity and preliminary study results. The site was fully surveyed and modeled with a one-dimensional hydraulic model, HEC-RAS. The geometry data then were input into a two-dimensional model, RMA2. Output from both models was used to calculate pier-scour estimates. Contraction scour was calculated using only output from the one-dimensional model.

A high discharge measurement made on August 17, 1967, at the Tanana River, was used to calibrate both models. The models were run with four discharge scenarios using discharge in the Tanana River for 100- and 500-year recurrence intervals, and, because discharge in the Nenana River has a considerable effect on the flow conditions at the bridge, using low and high discharges in the Nenana River. Discharge measured in the Nenana River during the study survey was used for low flow and the discharge for a 100-year recurrence interval in the Nenana River was used as high flow.

The models also were used to simulate the discharge at the time of the survey. The one-dimensional model did relatively well using the same roughness values as used for the higher flows. The simulated water surface was 0.5 to 1 foot higher than that surveyed in the field. The two-dimensional model required a reduction in roughness to properly simulate the lower flow. Surveyed data and computational mesh were too coarse, creating an artificial roughness from the jagged edges. This shortcoming was offset by reducing the roughness factor. Additional surveying and a refinement of the mesh would be required to use the two-dimensional model for reliable low-flow simulations.

Water-surface profiles computed by each model were similarly shaped. The greatest difference in water surface elevation was less than 1.5 feet, near the mouth of the Nenana River, the area with the greatest horizontal two-dimensional flow variability. In reaches where flow directions are not as variable, the shape and slope of the profiles match closely. In scenarios with high discharge in the Nenana River, water surfaces upstream of the bridge were higher in the twodimensional model than those in the one-dimensional model. This is due to the increase in cross-channel flow, which was simulated by the two-dimensional model but not by the onedimensional model. 
The models also determined the division of flow between the Tanana River main channel and the slough channel. With low flow in the Nenana River, the flows in the slough were similar between the models. For high flows in the Nenana River, the two-dimensional model simulated significantly higher flows in the slough because of the higher computed water surface upstream of the bridge. Pier-scour depth was calculated for all flood scenarios using output from both models. Estimates of pier-scour depth from the twodimensional model output were within 6 percent of those from the one-dimensional model output.

Flow characteristics near the mouth of the Nenana River and upstream of the bridge over the main channel varied considerably between the two models. However, results from the scour calculations for the two-dimensional model were slightly higher, but within 5 percent of those from the onedimensional model. The ability to compute an angle of attack from the two-dimensional model output rather than estimating an angle for the one-dimensional output greatly improved reliability of the scour estimate. Although the final results were similar, the two-dimensional model provided additional information about flow characteristics throughout the study reach and would be more useful for design or analysis than the one-dimensional model.

\section{References Cited}

Arcement, G.J., Jr., and Schneider, V.R., 1989, Guide for selecting Manning's roughness coefficients for natural channels and flood plains: U.S. Geological Survey WaterSupply Paper 2339, 38 p.

Brabets, T.P., Meade, R.H., and Wang, B., 2000, Environmental and hydrologic overview of the Yukon River basin, Alaska and Canada: U.S. Geological Survey WaterResources Investigations Report 99-4204, 106 p.

Brunner, G.W., 1997a, HEC-RAS, River analysis system hydraulic reference manual-Version 2.0: U.S. Army Corps of Engineers Hydrologic Engineering Center, 241 p.

Brunner, G.W., 1997b, HEC-RAS, River analysis system user's manual-Version 2.0: U.S. Army Corps of Engineers Hydrologic Engineering Center, 243 p.
Buchanan, T.H., and Somers, W.P., 1969, Discharge measurements at gaging stations: U.S. Geological Survey Techniques of Water-Resources Investigations, book 3, chap. A8, 65 p.

Burrows, R.L., Emmett, W.W., and Parks, Bruce, 1981, Sediment transport in the Tanana River in the vicinity of Fairbanks, Alaska, 1977-79: U.S. Geological Survey WaterResources Investigations Report 81-20, 56 p.

Burrows, R.L., and Harrold, P.E., 1983, Sediment transport in the Tanana River near Fairbanks, Alaska, 1980-81: U.S. Geological Survey Water-Resources Investigations Report 83-4064, 116 p.

Donnell B.P., Letter, J.V., Jr., McAnally, W.H., and Thomas, W.A., 2000, Users guide to RMA2 WES Version 4.5: U.S. Army Corps of Engineers Waterway Experiment Station, 264 p.

Environmental Modeling Research Laboratory, 1999, Surfacewater modeling system reference manual (version 7): Provo, Utah, Environmental Modeling Systems, Inc., 342 p.

Heinrichs, T.A., Kennedy, B.W., Langley, D.E., and Burrows, R.L., 2001, Methodology and estimates of scour at selected bridge sites in Alaska: U.S. Geological Survey WaterResources Investigations Report 00-4151, 44 p.

Holnbeck, S.R., and Parrett, C., 1997, Method for rapid estimation of scour at highway bridges based on limited site data: U.S. Geological Survey Water-Resources Investigations Report 96-4310, 79 p.

Interagency Advisory Committee on Water Data, 1982, Guidelines for determining flood-flow frequency: Hydrology Subcommittee, Bulletin 17B, 28 p.

Jones, S.H., and Fahl, C.B., 1994, Magnitude and frequency of floods in Alaska and conterminous basins of Canada: U.S. Geological Survey Water-Resources Investigations Report 93-4179, $122 \mathrm{p}$.

Melville, B.W., and Coleman, S.E., 2000, Bridge scour: Highlands Ranch, Colo., Water Resources Publications, 550 p.

Richardson, E.V., and Davis, S.R., 1995, Evaluating scour at bridges ( $3^{\text {rd }}$ ed.): Federal Highway Administration, FHWA-IP-90-017 HEC-18, 204 p. 
This page is intentionally blank. 
Manuscript approved for publication, January 20, 2006

Prepared by the U.S. Geological Survey Publishing Network,

Publishing Service Center, Tacoma, Washington

Bill Gibbs

Linda Rogers

Debra Grillo

Bobbie Jo Richey

For more information concerning the research in this report, contact the Director, Alaska Water Science Center

U.S. Geological Survey, 4230 University Drive

Anchorage, AK 99508

http://ak.water.usgs.gov 
畺

$\stackrel{\text { 물 }}{\stackrel{0}{\gtrless}}$

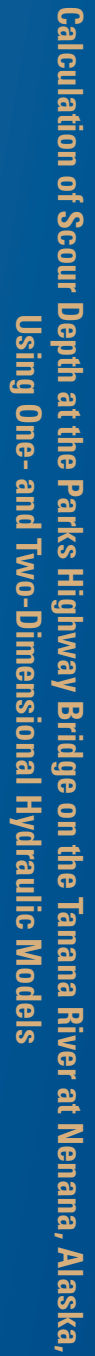

